\title{
POPULATION BIOLOGY AND DISTRIBUTION OF THE TANAID Kalliapseudes schubarti MAÑE-GARZON, 1949, IN AN INTERTIDAL FLAT IN SOUTHEASTERN BRAZIL
}

\author{
LEITE, F. P. P., ${ }^{1}$ TURRA, A. ${ }^{2}$ and SOUZA, E. C. F. ${ }^{2}$ \\ ${ }^{1}$ Departamento de Zoologia, IB, Unicamp, C.P. 6109, CEP 13083-970, Campinas, SP, Brazil \\ ${ }^{2}$ Programa de Pós-graduação em Ecologia, Departamento de Zoologia, IB, \\ Unicamp, C.P. 6109, CEP 13083-970, Campinas, SP, Brazil \\ Correspondence to: Fosca Pedini Pereira Leite, Departamento de Zoologia, IB, Unicamp, \\ C.P. 6109, CEP 13083-970, Campinas, SP, Brazil, e-mail: fosca@unicamp.br \\ Received October 2, 2001 - Accepted June 12, 2002 - Distributed August 31, 2003
}

(With 7 figures)

\begin{abstract}
The population biology and the spatial and temporal distribution of Kalliapseudes schubarti MañéGarzon, 1949, a common tanaidacean in mud flats and estuaries in southern and southeastern Brazil, was studied in the Araçá region, São Sebastião (SP), Brazil. This species showed a clustered dispersion in the area and the individuals were concentrated in the superficial sediment layer $(5 \mathrm{~cm})$. Higher densities of $K$. schubarti were recorded in areas characterized by moderately sorted fine sediment. Multiple regression analysis revealed a positive influence of the organic matter contents and a negative effect of the silt-clay contents on the abundance of $K$. schubarti. This species showed a marked temporal variation with very low abundance in winter and fall (March to August). Sexual dimorphism was evidenced with males being larger than females. Ovigerous females were also larger than pre-ovigerous ones. Sex ratio was skewed towards females. Seven cohorts were identified during the sampling period, the estimated longevity was 12 months, and no seasonal oscillation in growth was evidenced. The continuous reproduction, as evidenced by the presence of larval phases (manca II and neutron) and reproductive females throughout the year, and high fecundity among the tanaids associated with fast growth and limited longevity support the case for the opportunistic life strategy suggested for this species in the literature.
\end{abstract}

Key words: Tanaidacea, Kalliapseudes schubarti, temporal distribution, spatial distribution, population structure, population growth, sex ratio, fecundity, reproductive period.

\section{RESUMO}

\section{Biologia populacional e distribuição do tanaidáceo Kalliapseudes schubarti Mañé-Garzon,} 1949, em um terraço entremarés no Sudeste brasileiro

A biologia populacional e a distribuição espacial e temporal de Kalliapseudes schubarti Mañé-Garzon, 1949, tanaidáceo comum em estuários e planícies lodosas do Sul e Sudeste do Brasil, foi estudada na região do Araçá, São Sebastião (SP), Brasil. Essa espécie apresentou distribuição agrupada na área amostrada e os indivíduos concentraram-se na camada superficial $(5 \mathrm{~cm})$ do sedimento. Altas densidades de $K$. schubarti foram obtidas em áreas caracterizadas por sedimento fino e moderadamente selecionado. A análise de regressão múltipla revelou influência positiva dos teores de matéria orgânica e efeito negativo dos teores de silte-argila sobre a abundância de $K$. schubarti. Além disso, essa espécie apresentou variação temporal com diminuição em abundância no outono e inverno (março a agosto). Um dimorfismo sexual foi verificado, com machos sendo maiores que fêmeas. Fêmeas ovígeras também foram maiores que as pré-ovígeras. A razão sexual mostrou-se desviada para fêmeas. Sete coortes foram identificadas durante o período de amostragem. A longevidade estimada para K. schubarti foi 
de 12 meses e nenhuma oscilação sazonal no crescimento foi comprovada. A reprodução contínua, evidenciada pela presença de fases larvais (manca II e nêutron) e fêmeas reprodutivas ao longo do ano, e a alta fecundidade dentre os tanaidáceos, associada ao rápido crescimento e à pequena longevidade, suportam uma estratégia de vida oportunista sugerida para essa espécie na literatura.

Palavras-chave: Tanaidacea, Kalliapseudes schubarti, distribuição temporal, distribuição espacial, crescimento populacional, razão sexual, fecundidade, período reprodutivo.

\section{INTRODUCTION}

Tanaids are typically represented by marine forms with the majority of the 700 known species having been reported in deep-water environments. Although relatively few species live in marine coastal habitats (Pires, 1980; Masunari \& Sieg, 1980), they constitute a significant group especially in soft bottoms (Lana \& Guiss, 1991; Leite, 1995). However, tanaidacean biology, life history, and reproduction are still poorly known (Buckle-Ramirez, 1965; Johnson \& Attramadal, 1982; Messing, 1983; Modlin \& Harris, 1989).

Kalliapseudes schubarti Mañé-Garzon, 1949, is restricted to Brazil and Uruguai (Lang, 1956; Bemvenuti, 1987; Lana \& Guiss, 1991) and is an important component of macrobenthic soft-bottom intertidal and shallow water communities. This species is especially abundant in some beaches of the São Sebastião Channel (Leite, 1995; Nucci et al., 2001). Various studies have been done focusing on the biology of this species in southern and southeastern Brazilian coast (Bemvenuti, 1987; Lana et al., 1989; Almeida, 1994; Leite, 1995). The association of this tanaid with the sea grasses Ruppia maritima (Asmus, 1984) and Spartina alterniflora (Lana \& Guiss, 1991) was also reported. The species is also an important component of the diet of fishes and decapods (Capitoli et al., 1978). Despite its importance and widespread distribution in very different coastal environments there is little information on its reproductive biology and population structure. Moreover, the way the environment influences the abundance of this species is not well understood.

The aim of this study was to describe the spatial and temporal distribution of Kalliapseudes schubarti in an intertidal flat in southeastern Brazil, concentrating on its depth distribution in the sediment, dispersion pattern, and the relationships between abundance and environmental variables. The study also describes the population structure in the area by presenting information on sex ratio, size frequency distribution of different reproductive classes, population growth, reproductive period, and fecundity.

\section{MATERIAL AND METHODS}

This study was carried out in the Araçá region $\left(23^{\circ} 49^{\prime} \mathrm{S}, 45^{\circ} 24^{\prime} \mathrm{W}\right)$, a protected low-tide terrace situated in the central part of the São Sebastião Channel, southeastern Brazil. The region is a manaltered mangrove with input of organically enriched fresh water. Two $0.025 \mathrm{~m}^{2}$ sediment samples were collected in 14 areas in the intertidal region from October 1989 to October 1990 using a rectangular corer $(0.05 \mathrm{~m} \times 0.5 \mathrm{~m})$. The sediment was collected to a depth of $10 \mathrm{~cm}$ and separated vertically in two $5 \mathrm{~cm}$ parts. The sampled sediment was washed with seawater in 1.0 and $0.4 \mathrm{~mm}$ mesh size overlapping sieves. The sediment retained in the $0.4 \mathrm{~mm}$ sieve was observed under stereomicroscope to separate the small-sized individuals of $K$. schubarti.

All individuals were measured with a millimetric ocular from the tip of the carapace to the distal medial margin of the pleotelson (total length, $\mathrm{mm}$ ). The developmental stages of $K$. schubarti were separated based on the size and morphology of the antennae and chelipeds (Almeida, 1994; Leite \& Leite, 1997). The females were classified into pre-ovigerous or preparatory (with oostegites) and ovigerous (with eggs or embryos). The larval phases included the both manca II and neutrum stages (Masunari, 1983; Messing, 1983; Leite \& Leite, 1997). Non-reproductive individuals were those bearing chelipeds similar to those of the females but without oostegites, thus including nonreproductive ripe females and a small number of immature males and females. This classification was used since males could not be differentiated from females until exhibiting the larger chelipeds and the antennae (Leite \& Leite, 1997). The sex ratio calculation thus followed Mendoza (1982) and Almeida (1994). Mendoza (1982) studied Leptochelia dubia and 
classified as juveniles all individuals measuring less than the smallest identifiable male which in the present study measured $1.62 \mathrm{~mm}$. Almeida (1994) studied $K$. schubarti in southern Brazil and computed in the analysis only individuals larger than the smallest size class and having a representative number of males (4.5 $\mathrm{mm}$ ). This size class was equivalent to $3.5 \mathrm{~mm}$ in the present study.

The eggs or embryos were removed from the brood pouch (marsupium), counted, measured at the widest diameter, and classified according to developmental stage (Leite \& Leite, 1997) (Table 1).

Environmental variables were recorded for each sampling area and period. The sediment was analyzed in relation to granulometry (Suguio, 1973) and contents of organic matter and calcium carbonate (Amoureux, 1966). Salinity of the interstitial water was also recorded using a refractometer.

Statistical analyses were based on Zar (1999) with the significance level set at 0.05 . The KruskalWallis test was used to compare the abundance of $K$. schubarti among sampling areas (using months as temporal replicates) and months (using areas as spatial replicates). This test was also employed to verify spatial and temporal variations in salinity, sediment grain size, sorting coefficient, and contents (\%) of silt-clay, calcium carbonate, and organic matter. Single and multiple regression analyses were conducted to relate abundance of $K$. schubarti to environmental variables. The MannWhitney U-test was used to verify differences in the abundance of $K$. schubarti between the upper $(0-5 \mathrm{~cm})$ and lower $(5-10 \mathrm{~cm})$ sediment layers. A dispersion index (Elliot, 1977) was calculated to address the dispersion pattern of individuals in the sampled area. The log-likelihood G-test was used to test sex ratio for skewness from 1:1. The ANOVA and Scheffé's test for multiple pair-wise comparisons were performed after square root transformation to contrast the sizes of males, females (ovigerous and pre-ovigerous pooled), non-reproductive individuals and larval phases. Sizes of ovigerous and pre-ovigerous females was compared through the Student $t$ test. The relationship between female size and the number of eggs was estimated by simple linear regression analysis. The mean number of eggs (clutch size) and the maximum egg diameter were compared among the embryonic stages through ANOVA and Scheffé's test.

Population growth was estimated based on monthly size frequency histograms using modal progression analysis (Bhattacharya's method) and the Von Bertalanffy growth function (VBGF) with FISAT software (Guayanilo \& Pauly, 1997).

\section{RESULTS}

\section{Distribution}

Kalliapseudes schubarti showed a clustered dispersion in the study area $(\mathrm{n}=139, \mathrm{I}=128197.278$, $\mathrm{d}=489.771, \mathrm{p}<0.001)$ and was concentrated in the upper layer of the sediment (upper $5 \mathrm{~cm} ; 300.09 \pm$ 527.65 individuals) instead of the lower one (lower $5 \mathrm{~cm} ; 34.40 \pm 83.99$ ind., Mann-Whitney, $\mathrm{U}=$ $6,374.000, \mathrm{df}=1, \mathrm{p}<0.001)$. The abundance of $K$. schubarti varied markedly among sampling areas (Kruskal-Wallis, $\mathrm{H}=68.029$, df = 13, $\mathrm{p}<0.001$ ), being higher in areas 3, 4, 5, and 7 (Fig. 1). This species also showed temporal variation in abundance $(\mathrm{H}=30.240, \mathrm{df}=12, \mathrm{p}=0.003)$ with higher values recorded in October and November/89, declining thereafter until August/90 (Fig. 2). The number of individuals increased slightly at the end of the studied period (September and October/90).

Almost all physicochemical variables (except salinity) varied significantly among sampling areas (Fig. 3). The studied areas could be clearly divided into two regions (1 to 8 and 9 to 14 ) based on the values of the mean grain size, sorting coefficient, and organic matter content (see Fig. 3). The mean silt-clay content was high (> 4.0\%) in all samples and reached values superior to $13 \%$ in the areas 2, 6 , and 10. Calcium carbonate content was superior to $10 \%$ in areas 1, 2, 6 and 10 . Temporal analysis of the environmental variables revealed that only salinity and silt-clay and organic matter contents varied significantly over the studied period (Fig. 4). The variation in silt-clay content was very similar to that of the organic matter after December/ 89 while salinity showed lower values at the end of the sampling period (March to October/90).

No significant correlation was found between abundance of $K$. schubarti and the environmental variables in relation to either sampling areas or months, except for the positive relationship with the organic matter content $\left(n=14 ; r^{2}=0.606 ; p<0.001\right)$. However, the multiple regression analysis revealed a positive influence of organic matter and a negative effect of silt-clay content on the abundance of $K$. schubarti $\left[\mathrm{n}=14 ; \mathrm{r}^{2}=0.744 ; \mathrm{p}=0.001 ; \mathrm{y}=-2.239+\right.$ 174.300 (organic matter content) -26.031 (silt-clay content)]. 


\section{TABLE 1}

Fecundity of Kalliapseudes schubarti. ANOVA was used to compare the mean number of eggs (clutch size) and the maximum egg diameter among embryonic stages. Results of ANOVA are shown in the body of the table. Superscript labels indicate the results of the Scheffé's test for multiple pairwise comparisons. Classification of embryonic stages based on Leite \& Leite (1997).

\begin{tabular}{|c|c|c|c|}
\hline Embryonic stage & $\mathbf{N}$ & Mean & SD \\
\hline \multicolumn{4}{|l|}{ Clutch size } \\
\hline Round eggs $^{\mathrm{a}}$ & 41 & 11.829 & 7.707 \\
\hline Oval eggs ${ }^{b}$ & 79 & 8.114 & 4.154 \\
\hline Manca I ${ }^{\mathrm{b}}$ & 96 & 7.760 & 4.521 \\
\hline \multirow[t]{2}{*}{ Manca II $^{\mathrm{b}}$} & 228 & 8.461 & 4.602 \\
\hline & \multicolumn{3}{|c|}{ ANOVA: $\mathrm{F}=7.250, \mathrm{df}=3, \mathrm{p}<0.001$} \\
\hline \multicolumn{4}{|l|}{ Maximum diameter* } \\
\hline Round eggs $^{\mathrm{a}}$ & 41 & 0.393 & 0.106 \\
\hline Oval eggs ${ }^{\mathrm{a}}$ & 77 & 0.434 & 0.093 \\
\hline Manca I $^{\mathrm{b}}$ & 95 & 0.534 & 0.172 \\
\hline \multirow[t]{2}{*}{ Manca II ${ }^{\mathrm{c}}$} & 222 & 1.228 & 0.332 \\
\hline & \multicolumn{3}{|c|}{ ANOVA: $\mathrm{F}=434.237, \mathrm{df}=3, \mathrm{p}<0.001$} \\
\hline
\end{tabular}

* Log $(\mathrm{x}+1)$ transformation.

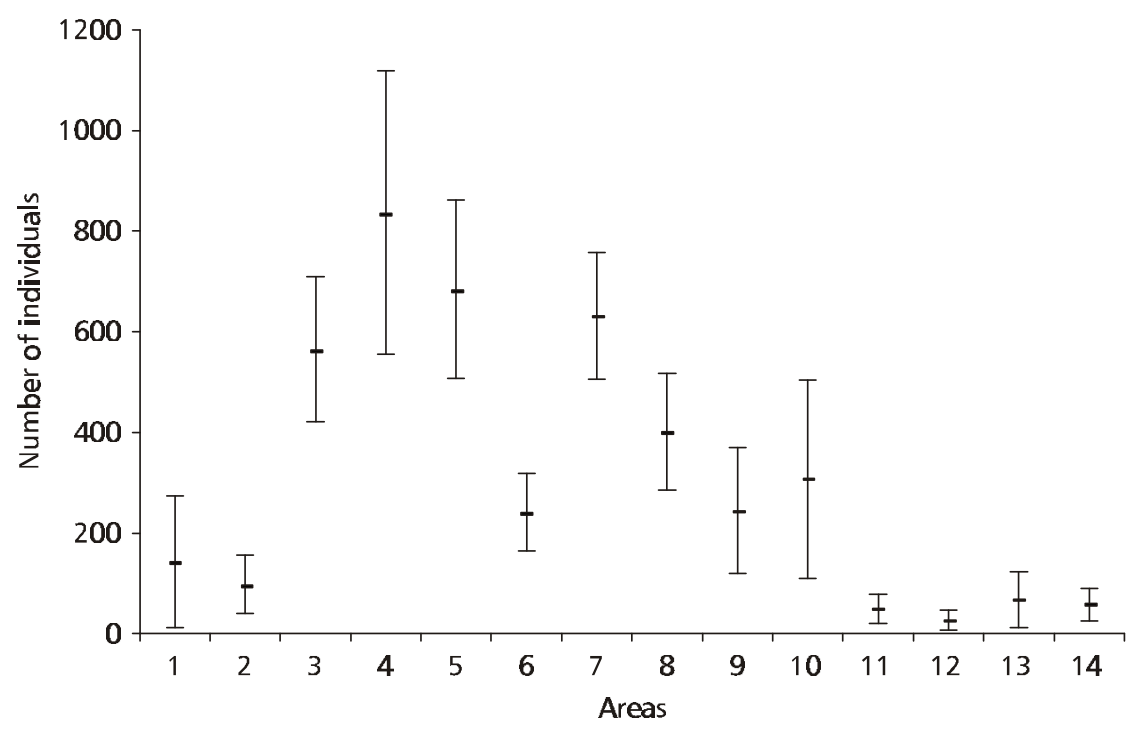

Fig. 1 - Mean ( \pm SE) number of individuals of Kalliapseudes schubarti in the sampled areas in the intertidal region of Araçá, São Sebastião Channel, southeastern Brazil. 


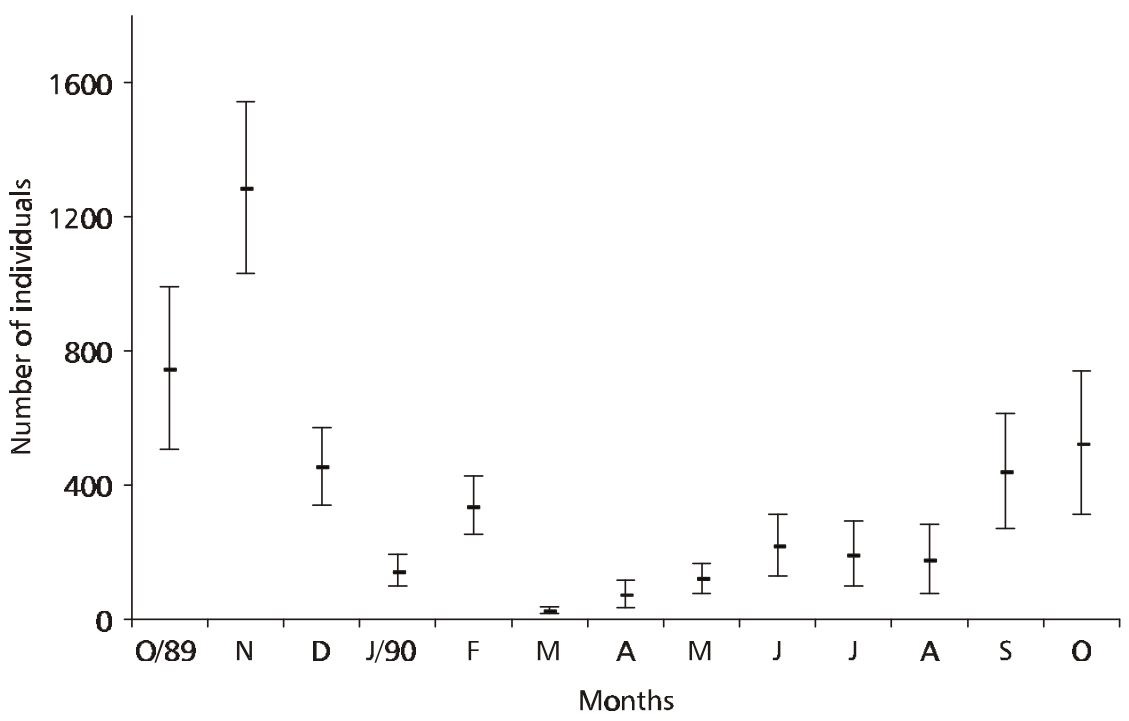

Fig. 2 - Mean ( \pm SE) number of individuals of Kalliapseudes schubarti during the sampled period (October 1989 to October 1990) in the intertidal region of Araçá, São Sebastião Channel, southeastern Brazil.

\section{Population biology and growth}

The species showed a mean size of $4.91 \pm 1.71$ $\mathrm{mm}$. Males, females, non-reproductive individuals and larval phases differed in length (ANOVA, square root transformation, $\mathrm{F}=3,800.196, \mathrm{df}=3, \mathrm{p}<0.001$ ) (Fig. 5). Larval phases showed a mean length of $1.95 \pm 0.39$ $\mathrm{mm}$ and were smaller than those of the other reproductive classes (Scheffé's test, $\mathrm{p}<0.001$, for all comparisons). Non-reproductive individuals were on average smaller $(4.05 \pm 1.09 \mathrm{~mm})$ than females $(6.87 \pm 1.11 \mathrm{~mm}$, Scheffé's test, $\mathrm{p}<0.001)$ and males $(5.79 \pm 1.22 \mathrm{~mm}, \mathrm{p}<0.001)$. Females were on average larger than males $(\mathrm{p}<0.001)$ while ovigerous females $(7.23 \pm 0.94 \mathrm{~mm}, \mathrm{p}<0.001)$ were on average larger than pre-ovigerous females $(6.63 \pm$ $1.15 \mathrm{~mm}, \mathrm{t}$ test, $\mathrm{t}=10.483, \mathrm{df}=1,365, \mathrm{p}<0.001)$. The smallest ovigerous female was $5.02 \mathrm{~mm}$.

The calculation of the population sex ratio based on Almeida (1994) (selected size class: 3.5 $\mathrm{mm})$ made possible an estimate of $2: 1$, skewed towards females (3959 females and 1942 males; Loglikelihood G-test: $\mathrm{G}=703.518, \mathrm{df}=1, \mathrm{p}<0.001)$. The procedure of considering the smallest male in the study population, following Mendoza (1982) (1.62 mm, see Fig. 5) produced a sex ratio estimate of 2.69:1 skewed towards females (5221 females and 1942 males; Log-likelihood G-test: $\mathrm{G}=$ $3,581.500, \mathrm{df}=1, \mathrm{p}<0.001)$.
Seven cohorts (modal progressions) were identified during the sampling period (Fig. 6) and followed by up to 5 months. Few individuals were sampled from March to May/89, making difficult modal identification. The modal progression indicated similar results similar to those of the VBGF for the population growth. The estimated maximum longevity was 12 months with a $\mathrm{K}$ (growth curvature parameter) = 3.0 and $\mathrm{L}_{\infty}$ (asymptotic length) $=10.7 \mathrm{~mm}$. No seasonal oscillation in growth was evidenced.

\section{Reproduction}

A highly variable frequency of larval phases (manca II and neutron) and ovigerous females was recorded over the sampling period (Fig. 7). Two peaks of larval phases were recorded in NovemberDecember/89 and July-August/90. Ovigerous females occurred over the entire period with peaks in November/89, February/90, April/90 (low number of individuals), and July/90.

Fecundity in the first developmental stage showed a mean value of 11.8 eggs (variation: 1 to 31 ), which decreased during embryonic development (Table 1). Later embryonic stages were also larger than the earlier ones (Table 1). Fecundity presented a weak, and non-significant, tendency to increase with female's size $\left(r^{2}=0.072, n=41\right.$, $\mathrm{p}=0.090)$. 

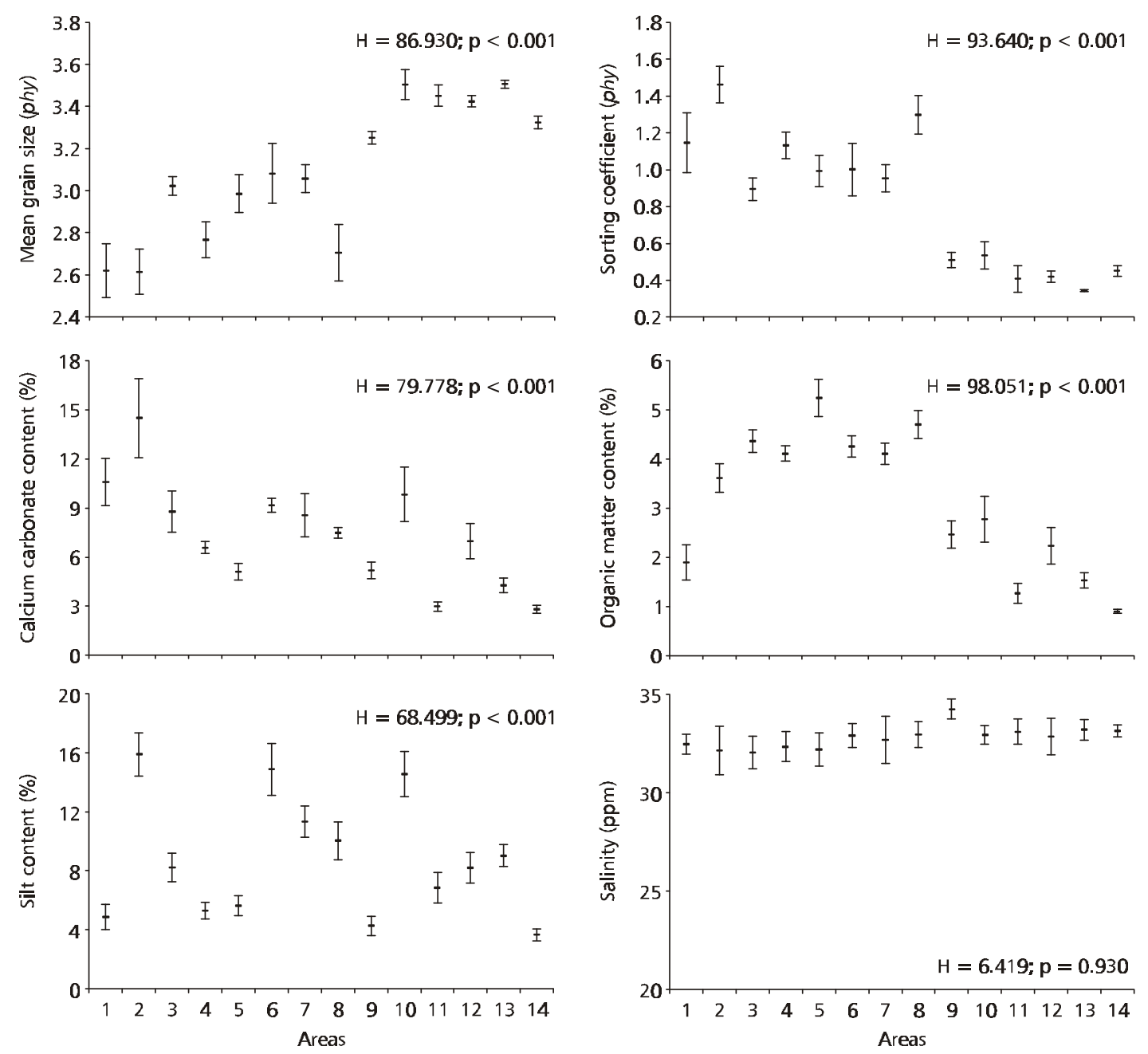

Fig. 3 - Physical and environmental variables (mean \pm SE) in the sampled areas. P-values indicate the probability associated with the Kruskal-Wallis test $(\mathrm{H})(\mathrm{df}=13$ for all comparisons).

\section{DISCUSSION}

\section{Distribution}

The clustered dispersion of Kalliapseudes schubarti was previously recorded in other areas (Bemvenuti, 1983; Lana et al., 1989; Lana \& Guiss, 1991; Almeida, 1994) and may be related to the settlement of juveniles in the vicinity of the adult tubes, as observed in other tube building tanaids (Johnson \& Attramadal, 1982; Borowsky, 1983). In addition, the patchy distribution of this population of $K$. schubarti was modulated closely associated to the environmental heterogeneity of the study area. In fact, the density of $K$. schubarti in Araçá was positively related to the organic matter content and negatively affected by the silt-clay contents. High contents of organic matter are in general associated to the fine sediment (Bemvenuti et al., 1978; Couto et al., 1995; Rosa-Filho \& Bemvenuti, 1998). In fact, the highest abundance of $K$. schubarti was observed in the areas 1-8, which were composed of fine (phy: 2.8 to 3.1 ) and moderately selected (phy 1.0) sediment. In contrast, areas 9-14 were made up of very fine wellsorted sand and had the smallest abundances of K. schubarti. 

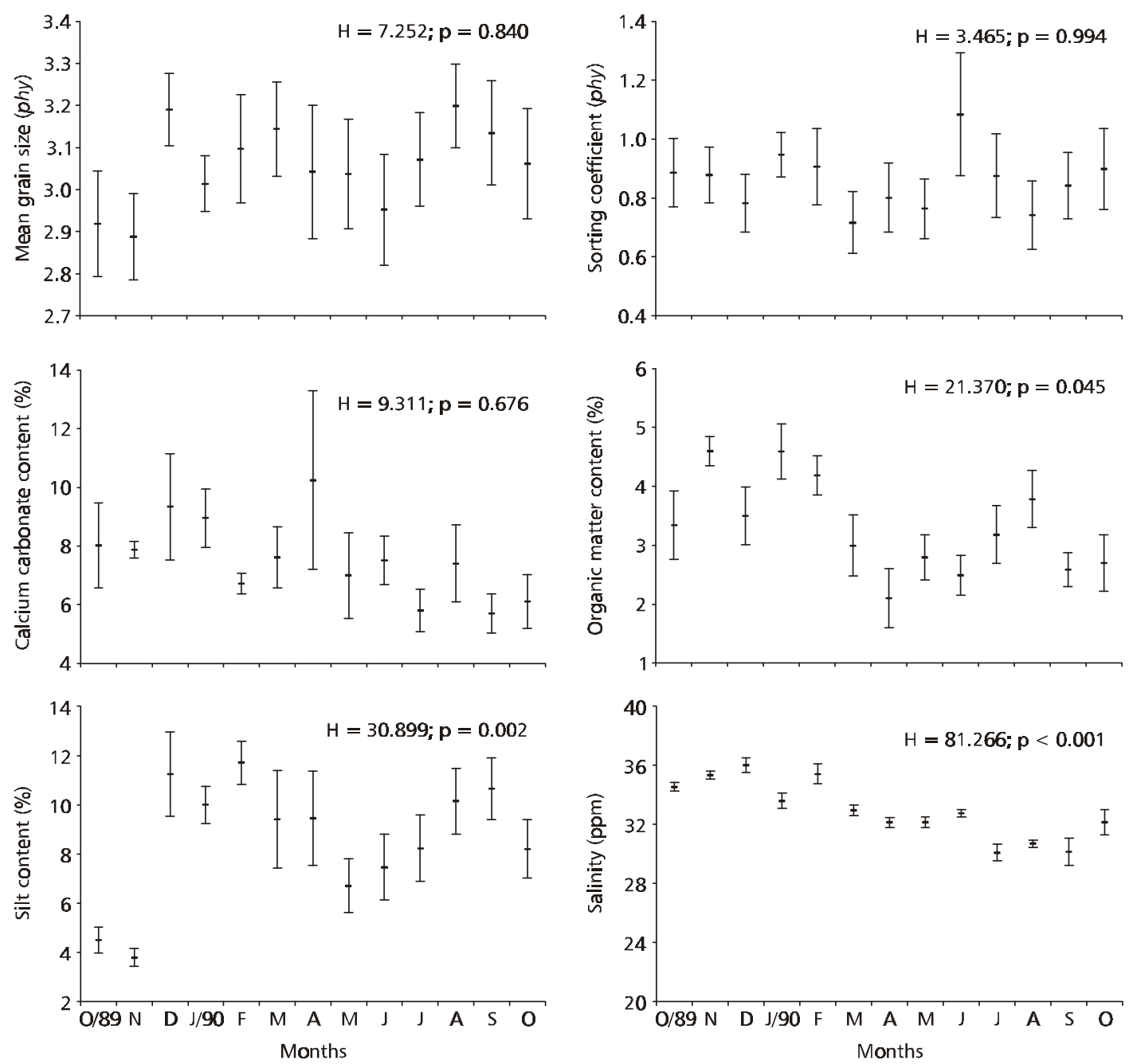

Fig. 4 - Physical and environmental variables (mean $\pm \mathrm{SE}$ ) in the sampled months. P-values indicate the probability associated with the Kruskal-Wallis test $(\mathrm{H})(\mathrm{df}=12$ for all comparisons).

The low abundance in areas 1 and 2 may be attributed to physical barriers like shell fragments, indicated by the high calcium carbonate contents, which could prevent tube building by $K$. schubarti like seagrasses root systems (Bemvenuti, 1983).

Nucci et al. (2001) observed a marked reduction in the abundance of $K$. schubarti after a significant increase of silt-clay content (22\%) in the sediment when comparing this result with that of a previous study (9.9\%, Amaral et al., 1993). However, high densities of $K$. schubarti were also found in sediments with no (Almeida, 1994) or low silt-clay values
(0.87\% to $6.11 \%$ ) (Couto et al., 1995). In the Araçá region, silt-clay contents varied significantly among the sampling areas and periods, reaching values as high as $24.81 \%$. In this way, we propose that the abundance of $K$. schubarti may be positively influenced by low-to-intermediate silt-clay contents ( $4 \%$ to $10 \%)$, while very high values (>13\%) may have a negative effect. The significant salinity variation observed in the Araçá region does not seem to be an important factor in influencing the density and distribution of $K$. schubarti, probably because it is adapted to estuarine conditions. 

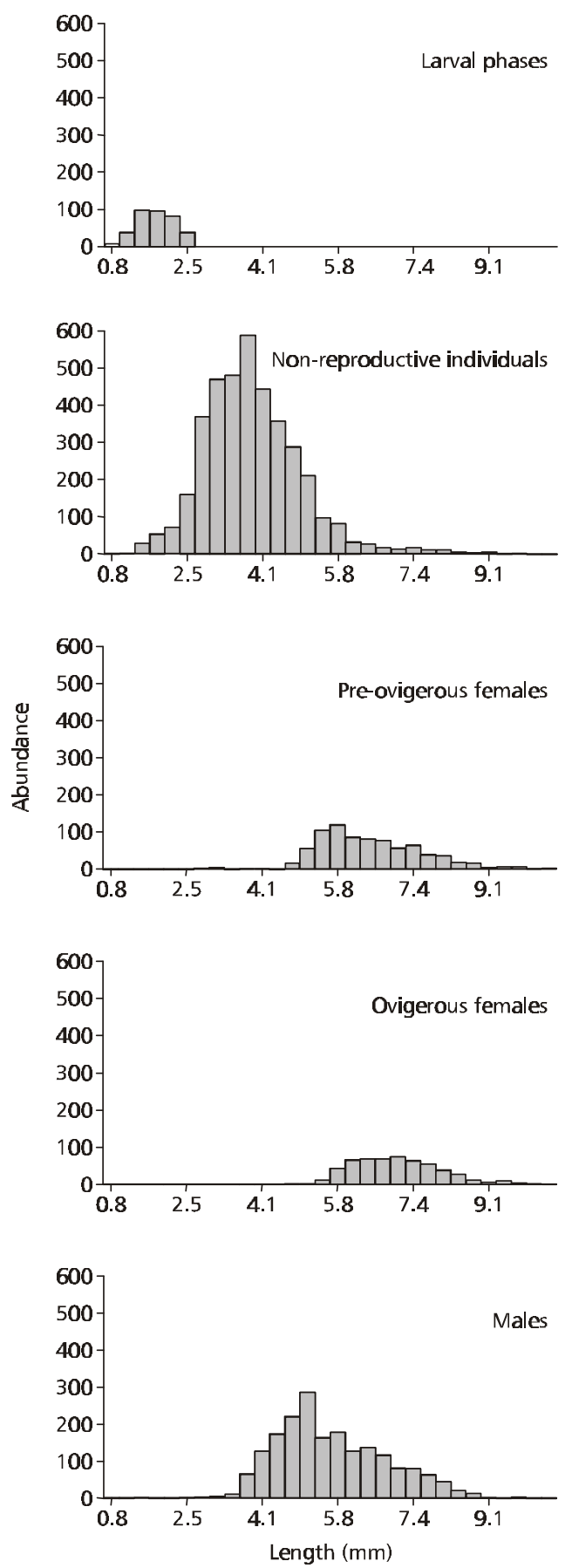

Fig. 5 - Frequency distribution of the size (total length, $\mathrm{mm}$ ) of larval phases (manca II and neutron), non-reproductive individuals, pre-ovigerous, and ovigerous females, and males of Kalliapseudes schubarti in the Araçá region of São Sebastião Channel, southeastern Brazil from October 1989 to October 1990. 


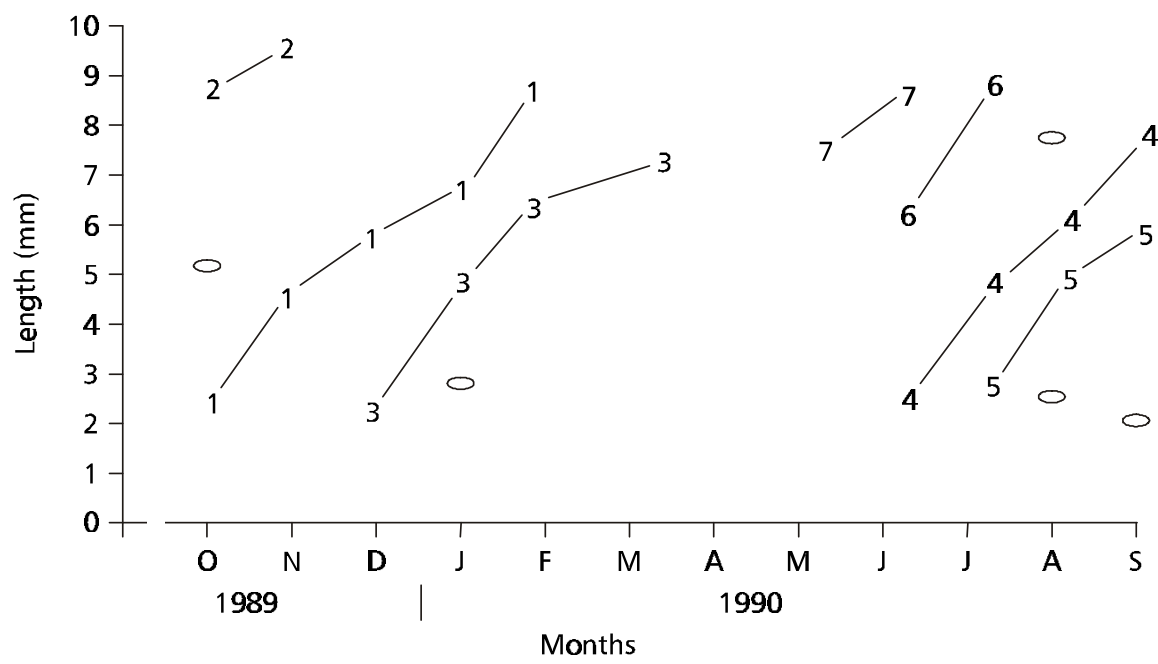

Fig. 6 - Modal progression analysis based on the size frequency distribution (total length, mm) of Kalliapseudes schubarti according to the method of Bhattacharya.

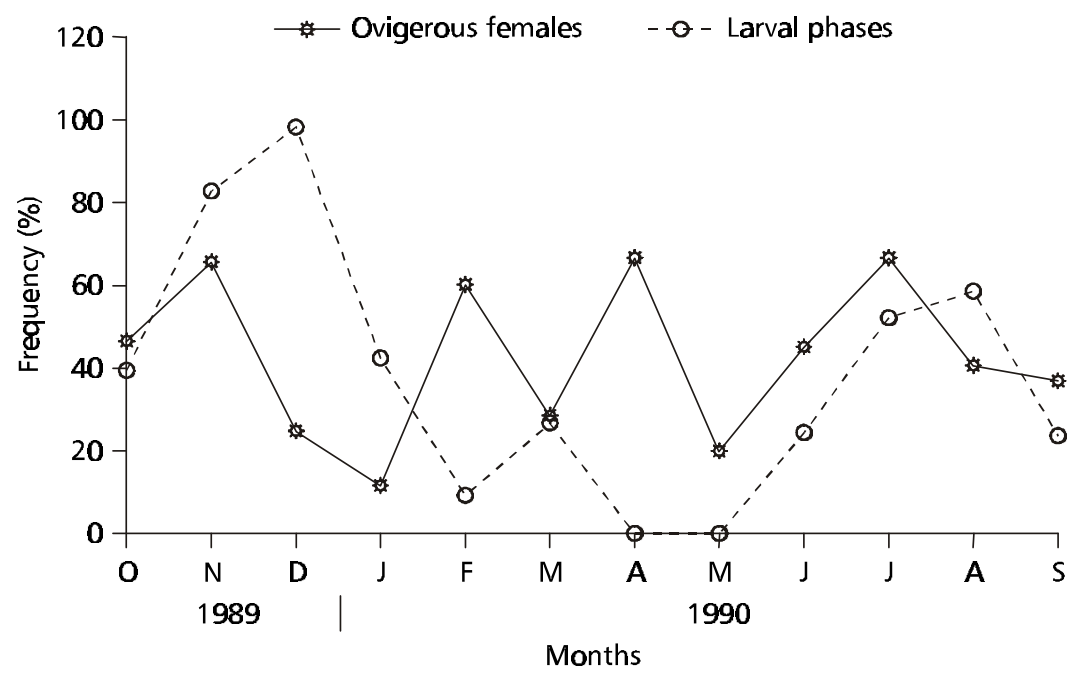

Fig. 7 - Frequency of juveniles and ovigerous females of Kalliapseudes schubarti in the Araçá region of São Sebastião Channel, southeastern Brazil, from October 1989 to October 1990.

The higher density of $K$. schubarti in the superficial layer could be attributed to the size of their tubes, the depths of which may vary from a few centimeters (Rosa-Filho \& Bemvenuti, 1998) to 20 cm (Bemvenuti, 1983). In Araçá the tubes of $K$. schubarti rarely exceed a depth of $5 \mathrm{~cm}$, probably due to a very superficial anoxic layer $(0-5 \mathrm{~cm}$, personal observation). Moreover, if juveniles are not able to built tubes as deep as adults can, the concentration of individuals in the upper $5 \mathrm{~cm}$ sediment layer could be a direct consequence of the high abundance of small-sized individuals in this population. 


\section{Population biology}

Kalliapseudes schubarti showed a population sex ratio skewed towards females as previously observed by Almeida (1994), which seems to be a rule among tanaid species (Mendoza, 1982; Masunari, 1983; Kneib, 1992; Lewis, 1998). Although the deviation from the expected proportion of 1:1 may be explained by factors related to the life cycles of each population (Wenner, 1972), it may also be attributed to the male reproductive behavior. Since fecundation of females of $K$. schubarti probably occurs inside the tube, as is the case with other tubicolous tanaids (Johnson \& Attramadal, 1982; Highsmith, 1983; Borowsky, 1983), mature males would have to leave their tubes to search out females (Highsmith, 1983; Borowsky, 1983). During this displacement they could be easily eaten by predators, resulting in a lower number of males in the population. The presence of $K$. schubarti in the diets of crabs and fishes (Capitoli et al., 1978), which was also observed for Leptochelia dubia (Mendoza, 1982), may support this hypothesis. Protoginic hermaphroditism may be taking place to compensate for the drastic decrease in males and to guarantee reproduction in this population (Brook et al., 1994). This is a common phenomenon among tanaids (Brook et al., 1994), associated also with low female mobility and intense competition among males to access females (Highsmith, 1983). The occurrence of two male forms in this population of K. schubarti (Leite \& Leite, 1997) also suggests the possibility of sequential protoginic hermaphroditism.

The number of modal progressions as well as the growth rate and the longevity of $K$. schubarti in Araçá were similar to those recorded by Almeida (1994) in a similar habitat and period (Saco do Limoeiro, Paraná State in 1989/1990). The extremely low number of individuals between March and May precluded following the modal progressions (or cohorts). Environmental alterations common to this area, e.g., sediment movements, algal growth (Ulva sp.), domestic sewage, and oil spills may be causing local and short-term reductions in abundance of this species.

\section{Reproduction}

The great width of the pre-ovigerous, ovigerous females and non-reproductive individuals of $K$. schubarti, may indicate the possibility of females reproducing more than once a year. This is suggested by the size overlap between non-reproductive individuals and mature females which have lost their oostegites after hatching [(oostegites may be form again for further reproduction (Johnson \& Attramadal, 1982)]. Although Almeida (1994) has suggested that females die after the first spawning.

The year-long presence of larval phases and reproductive females (ovigerous) in this population of $K$. schubarti is strong evidence of continuous reproduction, an advantageous strategy for small animals that carry few eggs (Lewis, 1998). The tanaids seem to be the peracarids with the lowest fecundity values (Messing, 1983). However, despite the wide variation in the number of eggs of $K$. schubarti, this species showed very high fecundity values (see comparative table in Messing, 1983). This high fecundity and continuous reproduction connected to fast growth and brief longevity support the case for the opportunistic life strategy of $K$. schubarti suggested by Bemvenuti (1987) and Lana et al. (1989).

There is a tendency, in K. schubarti, as well as in other tanaids (Masunari, 1983; Messing, 1983), toward a positive relationship between the number of eggs and the length of the females (see also Almeida, 1994). The weak correlation shown in the present study may be caused by egg loss during the sieving procedure. The decrease in number and increase in embryo size among developmental stages, may indicate that mortality is related to the space available in the brood pouch.

Acknowledgments - We wish to thank Fundação de Amparo à Pesquisa do Estado de São Paulo (FAPESP/Proc. № 89/ 0995-1) and Conselho Nacional de Desenvolvimento Científico e Tecnológico (CNPq/Proc. № 401300/89-7) for a grant and a fellowship (CNPq/Proc. № 300337-82-5) to F. P. P. Leite. We are grateful to Mylene P. Ramos for technical help and to Centro de Biologia Marinha da Universidade de São Paulo (CEBIMar USP) for logistical support.

\section{REFERENCES}

ALMEIDA, M. V. O., 1994, Kalliapseudes schubarti MañéGarzon, 1949 (Tanaidacea-Crustacea): dinâmica populacional e interações com a macrofauna bêntica no Saco do Limoeiro, Ilha do Mel (Paraná, Brasil). Tese de Mestrado, Universidade, Federal do Paraná. 79p.

AMARAL, A. C. Z., PARDO, E. V., MORGADO, E. H., REIS, M. O., SALVADOR, L. B. \& LIMA, L. H., 1993, Sobre a macrofauna bêntica entremarés de praias da Ilha de São Sebastião (SP). In: III Simpósio de Ecossistemas da Costa Brasileira: subsidios a um gerenciamento ambiental. Publicação ACIESP, 87(3): 330-337. 
AMOUREUX, L., 1966, Étude bionomique de qualques annélides polychétes des sables intertidauxs des côtes ouest de la France. Archs. Zool. Exp. Gên., 107: 1-218.

ASMUS, M. L., 1984, Estrutura da comunidade associada à Ruppia maritima no estuário da Lagoa dos Patos, Rio Grande do Sul. Tese de Mestrado, Fundação Universidade do Rio Grande, 154p.

BEMVENUTI, C. E., 1983, Efeitos da predação sobre as características estruturais de uma comunidade macrobentônica numa enseada estuarina da Lagoa dos Patos, RS, Brasil. Tese de Mestrado, Fundação Universidade do Rio Grande, 120p.

BEMVENUTI, C. E., 1987, Macrofauna bentônica da região estuarial da Lagoa dos Patos, RS, Brasil. In: Simpósio sobre Ecossistemas da Costa Sul e Sudeste Brasileira. ACIESP, São Paulo, 54(1): 428-459.

BEMVENUTI, C. E., CAPITOLI, R. R. \& GIANUCA, N. M., 1978, Estudos de ecologia bêntonica na região estuarial da Lagoa dos Patos. II. Distribuição quantitativa do macrobentos infralitoral. Atlântica, 3: 23-32.

BOROWSKY, B., 1983, Reproductive behavior of three tubebuiding peracarid crustaceans: the amphipods Jassa falcata and Ampithoe valida and the tanaid Tanais cavolinii. Mar. Biol., 77: 257-263.

BROOK, H. J., RAWLINGS, T. A. \& DAVIES, R. W., 1994, Protogynous sex change in the intertidal isopod Gnorimosphaeroma orogoense (Crustacea: Isopoda). Biol. Bull., 187: 99-111.

BUCKLE-RAMIREZ, L. F., 1965, Untersuchungen über die Bilogie von Heterotanais oestendi Kroyer (Crustacea, Tanaidacea). Z. Morph. Ökol. Tiere, 55: 714-782.

CAPITOLI, R. R., BEMVENUTI, C. E. \& GIANUCA, N. M., 1978, Estudo de ecologia bentônica na região estuarial da Lagoa dos Patos. I. As comunidades bentônicas. Atlântica, Rio Grande, 3: 5-22.

COUTO, E. C. G., ALMEIDA, M. V. \& LANA, P. C., 1995, Diversidade e distribuição espacial da macroinfauna bêntica do Saco do Limoeiro, Ilha do Mel, Paraná, outono de 1990. Bolm. Inst. Oceanogr., 11: 239-247.

ELLIOT, J. M., 1977, Some methods for the statistical analysis of samples of benthic invertebrates. Freshwater Biological Association on Scientific Publication, 25, 144p.

GUAYANILO, F. C. Jr. \& PAULY, D., 1997, FAO-ICLARM Stock Assessment Tools (FISAT). Reference manual. Home: FAO Computerized Information Series (Fisheries n. 8).

HIGHSMITH, R. C., 1983, Sex reversal and fighting behavior: coevolved phenomena in a tanaid crustacean. Ecology, 64(4): 719-726.

JOHNSON, S. B. \& ATTRAMADAL, T. G., 1982, Reproductive behavior and larval . development of Tanais cavolini (Crustacea: Tanaidacea). Mar. Biol., 71: 11-16.

KNEIB, R. T., 1992, Population dynamics of the tanaid Hargeria rapax (Crustacea: Peracarida) in a tidal marsh. Mar. Biol., 113: 437-445.

LANA, P. C. \& GUISS, C., 1991, Influence of Spartina alterniflora on structure and temporal variability of macrobenthic associations in a tidal flat of Paranaguá Bay (Southeastern Brazil). Mar. Ecol. Prog. Ser., 73: 231-244.
LANA, P. C., ALMEIDA, M. V. O., FREITAS, C. A. F., COUTO, E. C. G., CONTI, L. M. P., GONZALES-PERONTI, A. L., GILES, A. G., LOPES, M. J. S., SILVA, M. H. C. \& PEDROSO, L. A., 1989, Estrutura espacial de associações macrobênticas sublitorais da gamboa Perequê (Pontal do Sul, Paraná). Nerítica, 4(1/2): 119-136.

LANG, K., 1956, Tanaidacea aus Brasilien. Kieler Meeresf, 12(2): 249-260.

LEITE, F. P. P., 1995, Distribuição temporal e espacial de Kalliapseudes schubarti Mañé-Garzon, 1949 (Crustacea, Tanaidacea) na região do Araçá, São Sebastião (SP). Arq. Biol. Tecnol., 38(2): 605-618.

LEITE, F. P. P. \& LEITE, P. E. P., 1997, Desenvolvimento morfológico e dos ovários de Kalliapseudes schubarti MañéGarzon, (Crustacea, Tanaidacea) do Canal de São Sebastião, SP, Brasil. Rev. Bras. Zool., 145(3): 675-683.

LEWIS, J. B., 1998, Occurrence and distribution of the tanaid crustacean Leptochelia savignyi on the calcareous hydrozoan Millepora complanata. Bull. Mar. Sci., 63(3): 629-632.

MASUNARI, S., 1983, Post-marsupial development and population dynamics of Leptochelia savignyi (Kroyer, 1942) (Tanaidacea). Crustaceana, 44(2): 151-162.

MASUNARI, S. \& SIEG, J., 1980, Morphological and ecological notes on Zeuxo coralensis Sieg 1980 from Brazil. St. Neotr. Fauna Environ., 15: 1-8.

MENDOZA, J. A., 1982, Some aspects of the auto ecology of Leptochelia dubia (Kroyer, 1842) (Tanaidacea). Crustaceana, 43(3): 225-240.

MESSING, C. G., 1983, Post-marsupial development and growth of Pagurapseudes largoensis McSweeny (Crustacea, Tanaidacea). J. Crust. Biol., 3(3): 380-408.

MODLIN, R. F. \& HARRIS, P. A., 1989, Observations on the natural history and experiments on the reproductive strategy of Hargeria rapax (Tanaidacea). J. Crust. Biol., 9(4): 578-586.

NUCCI, P. R., TURRA, A. \& MORGADO, E. H., 2001, Diversity and distribution of crustaceans from 13 sheltered sandy beaches along São Sebastião Channel, southeastern Brazil. J. Mar. Biol. Assoc. UK, 81: 475-484.

PIRES, A. M. S., 1980, Ecological studies on intertidal and infralitoral Brazilian Tanaidacea (Crustacea, Peracarida). Stud. Neotr. Faun. Env., 15: 141-153.

ROSA-FILHO, J. S. \& BEMVENUTI, C. E., 1998, O sedimento como fator limitante para a distribuição de Kalliapseudes schubartii Mañé-Garzon 1949 (Crustacea, Tanaidacea) em fundos moles estuarinos. Nauplius, 6: 119-127.

SUGUIO, K., 1973, Introdução à sedimentologia. Blaucher/ EDUSP, São Paulo, 312p.

WENNER, A. W., 1972, Sex ratio as a function of size in marine Crustacea. Am. Nat., 106: 321-350.

ZAR, J. H., 1999, Biostatistical analysis. Prentice Hall, Englewood Cliffs, N. J., 4. ed., 718p. 